\title{
Consumers' Preference of Fast Food Items in Kathmandu Valley
}

\author{
Bharat Rai, MPhil \\ Rajshree Rawal \\ Lecturer \\ Nepal Commerce Campus, Faculty of Management, T.U.
}

\begin{abstract}
The main purpose of this study is to understand and evaluate the factors affecting consumer's preference of fast food items in Kathmandu Valley. Taste, price, ambience and location have been taken as independent variables and brand preference has been taken as dependent variable in the study. The study has been adopted the descriptive and causal research design. Sample size has been taken 226 under the study. Primary data for the research has been collected using structured questionnaire from fast food consumer within Kathmandu Valley of University students. To analyze the collected data, descriptive statistics, and Pearson correlation as well as regression analysis has been conducted to identify the relationship and effect between independent variables (taste, price, ambience and location) and dependent variable (consumer preference). SPSS has been used to process the data and to find the result of the data analysis.

By the correlation analysis there is significant relationships between independent variables (taste, price, ambience and location) and dependent variable (brand preference). Based on regression analysis, taste, ambience and location have significant and positive impact on consumer preference for fast food items. It means consumers are much more concerned and aware about these factors while consuming the fast food. Similarly, price has less or no effect on consumer preference for fast food items for the respondents taken under the study. Key words: Consumer's preference, taste, price, ambience, location.
\end{abstract}

\section{Background of the Study}

Consumers' preferences on fast food are very strong in some societies. This is because of the parallel changes in working and social life and habits of dining out. In social context, gradually the numbers of working families are increasing worldwide (Stamoulis, Kostas G. et al., 2004).

Consumer Preference is the term in which consumer like one thing over another. (Rapurohit \& Vasita, 2011), examine that consumer preference mainly to select an option that has the most likely among the number of options by consumer have to satisfy his/her need or desire. The result of their behavior that consumer prefer by showing while purchasing or searching the product.

The study of consumer preferences on fast food items is so much important as it investigates the trend and pattern of fast food consumption and the importance of various factors affecting the choice of fast food among the consumers. In today's world, the habit of taking fast food is changing very fast. People who are living in the city have high tendency to consume fast food compared to the people living in the rural areas. The reason for the change is the time factor. They do not have much time to prepare food at 
their home. As society develops, the economic activities also expand. Therefore, people become busy and that discourages them to prepare food at their home. As such, the only alternative is to consume food that is prepared by others and preferably light in nature. While people select fast food, a number of factors are considered by them (Islam \& Ullah, 2010).

In recent years, the major food consumption trend in urban parts of developing countries is that more consumers are eating increasingly more meals outside of their homes and most of the growth in away-fromhome eating has been in the fast food sector (Kaynak, Aksoy, \& Kucukemiroglu, 1996). The interest shown at the national and internationals levels concerning the fast foods is derived from the scarcirty of time in a competitive, dyanamic and urban fast life(Platania \& Privitera, 2006).

Normally job holders and students tend to have a busy schedule. Students away from their home have to cook themselves which not only affects their studies. They are often consciuos about how to save as much time as possible. In this regard fast food has help them manage their time and at least provide time for leisure (Kharel, 2015).

\section{Statement of Problem}

There is an increasing trend of customer attraction towards the fast food restaurants and their items. The fast food industry is booming and it is very important to find out the reason behind people preferring to eat and the overall customer satisfaction from having fast food items. There are certain factors that people look for while eating out at fast food items, which needed to be highlighted. There are fast food items in Nepal such as, momo, pizza, burger, chowmein, fries, sausage, roll, sandwich etc., which are gaining a huge popularity in the Nepalese Fast food industry. Therefore, this research will find the answers to these questions:

* What are the determinants for choosing any fast food items?

* Is there relationship between Independent variables (taste, price, ambience and location) and Dependent Variable (Consumer Preference)?

\section{Purpose of the Study}

The specific objectives are outlined below.

* To examine relationship between price, taste, ambience and location (independent variables) and consumer preference (dependent variable).

* To explore the impact of price, taste, location and ambience on the consumer's preferences on fast food items.

\section{Hypotheses}

In order to find which factor most affects the consumer preference of fast food items, the following are the research hypotheses of the study.

H1: There is significance effect of taste on consumer's preference in consuming fast food.

H2: There is significance effect of price on consumer's preference in consuming fast food.

H3: There is significance effect of ambience on consumer's preference in consuming fast food.

H4: There is significance effect of location on consumer's preference in consuming fast food.

\section{Literature Review}

Deivanai (2016) concluded that the Quality of product, Service quality, Environment internal and external, staff cooperation, Price, Taste of the product, convenient, place factors are responsible for satisfying nature.

Phan \& Nguyen (2016) examined the impacts, which are both direct and indirect, of the four cores such Service quality and Food quality, Price and Environment elements on customer satisfaction as well as loyalty in the Vietnam fast-food restaurant segment nowadays. Furthermore, these findings also provide 
Vol. 4, No. 1

useful strategies and understandable knowledge to improve and develop in Vietnamese fast-food restaurants as well as the satisfaction level from customers.

Naziret.al (2014) made a study to find out the factors that are important in satisfying fast food restaurant consumers. Customers prefer one restaurant over another on the basis of some factors/variables. The factors in our research on the basis of which preference is made are high quality of food, exceptional employee service, environmental and price and security. Some people consider price as an important factor in selecting a restaurant while some prefer quality and don't care of the high price.

Kumar and Radhika (2013) found that most of the consumers are satisfied with their choice of fast food outlets and would like to visit them often. From the study it can be concluded that the overall level of satisfaction of the respondents with regard to the service rendered at the fast food outlets is satisfactory. The study has brought out the customer preference of fast food and fast food outlets and also the factors that need to be improved.

Monteiro (2000) concluded that the important factors for the entire sample were quality of food, taste of the food, and hygiene and cleanliness, in descending order of importance, while availability of vegetarian choices, availability of new items, and cultural familiarity were the least important factors for the whole sample.

Prabhavathiet.al (2014) found that the affordable price of the menu and friends influence, Healthy menu and Service Quality, Taste and location proximity and Restaurant ambience were more important.

Islam \& Ullah (2010) conducted the research and found that the consumers give most importance on brand reputation of the food item followed by nearness to receive and accessibility, similarity of taste with previous experience, cost and quality of the food, discount and taste, cleanliness and hygiene, salesmanship and decoration, fat and cholesterol level, and self-service factors.

Ashraf et.al (2014) concluded that the six factors are hypothesized such as quality of food, quality of service, variety of food, environment of the outlets, price of food and location convenience to influence consumer satisfaction in fast food marketing. The findings indicate that all of the factors except price of food have significantly impacted on consumer satisfaction.

Khan, Hussain \&Yaqoob (2013) made a study and found that the service quality and brand are the key factors for satisfaction in fast food industry in Peshawar Pakistan. However there is a significant positive relationship between the Promotion, Service quality, Customer expectations, Brand, Physical Environment, Price, and Taste of the product to customer satisfaction.

Liu and Jang's (2009) study on ethnic restaurant in emotional influence to environmental dimensions was conducted and findings showed that environmental cleanliness and attentive service are two important areas where Chinese restaurateurs can make improvements. In addition; food taste and service reliability appear to bakery attributes for Chinese restaurants success. Overall, this study indicated that food quality, service reliability and environmental cleanliness were the three pivotal attributes to create satisfied customers and positive post-dining behavioral intentions.

\section{Conceptual Framework}

The theoretical framework is the structure that can hold or support a theory of a research study. This study intends to examine the factors affecting consumers' preference of fast foods items of

Based on above literature review the study suggets that the taste, price, ambience and location are the independent variable for brand preference for fast food items for the university stydents of Nepal. 
Figure no. 1 : Conceptual Framework

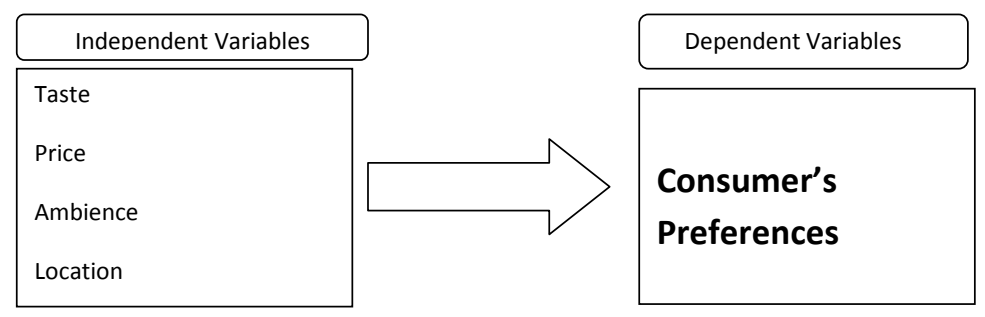

\section{Research Methodology}

Descriptive research design has been used to describe the situation and causal research design has been used to explore the cause and effect relationships.

In this study, the questionnaire has been designed to assess the consumer preference of fast food items in Kathmandu Valley.

The total populations of the study are the consumers who consume the fast food items within Kathmandu valley who have different taste for the fast food items, price of the fast food, location and ambience of the fast food. The sample size selected for the survey is 226 respondents. The sampling has been done using non probability convenient sampling technique.

Mean, standard deviation has been used to describe the collected data and correlation has been used to explore the relationship between independent variables (taste, price, ambience and location) and dependent variable (consumer's preference), regression analysis has been used to identify the impact of four independent variables (taste, price, ambience and location) on dependent variable (consumer's preference) as well.

\section{Data Analysis}

The data characteristics have been analyzed in terms of mean value and standard deviation of each of the variable taste, price, ambience, and location.

Table No. 1 Descriptive statistics

\begin{tabular}{lcc}
\hline & Mean & SD \\
Taste & 3.89 & 0.38 \\
Price & 3.65 & 0.502 \\
Ambience & 3.7 & 0.54 \\
Location & 3.81 & 0.43 \\
\hline
\end{tabular}

Source: Market Survey, 2018

All variables were rated on the brand preference scale with a score of indicating $1=$ strongly disagree, $2=$ disagree, $3=$ neutral $4=$ agree and $5=$ strongly agree. The above table indicates that the descriptive statistics of brand preference in fast food items. The result has shown the mean score of taste, price, ambience and location are 3.89, 3.65, 3.7, and 3.81, respectively, which are more than average value, it indicates that the respondents are positively inclined towards the statement and agreed to brand preference. It shows that all respondents are agreed or strongly agreed towards the brand preference for fast food items consumption. Likewise, the standard deviations have been recorded to be ranging from 0.38 to 0.54 which are consistent. It shows that the variability of data collected is significant to be used for the purpose of study. Thus, it can 
Vol. 4, No. 1

be concluded that the consumers are agree with the statements that taste, price, ambience and location have significant influence on consumer brand preference while consuming the fast food items in Kathmandu. So, taste, price, ambience and location influence in the consumer purchasing of fast food items.

\section{Correlation Analysis}

Pearson's correlation analysis has been carried out to analyze the degree of relationship between two or more variables and to know to what extent variables under study are correlated to each other.

Table no. 2 Correlation Analysis of Consumer Preference and Independent Variables.

\begin{tabular}{lccccc}
\hline Pearson & Preference & Taste & Price & Ambience & Location \\
\hline Preference & 1 & & & & \\
Taste & $.544^{* *}$ & 1 & & & \\
Price & $.337^{* *}$ & $.030^{* *}$ & 1 & & \\
Ambience & $.518^{* *}$ & $.070^{* *}$ & $.616^{* *}$ & 1 & 1 \\
Location & $.466^{* *}$ & $.020^{* *}$ & $.512^{* *}$ & $.689^{* *}$ & \\
\hline **. Correlation is significant at the 0.01 level (2-tailed) & & \\
\hline
\end{tabular}

Source: Market Survey 2018

The above table shows the result of the Pearson's correlation coefficient between consumer preference and the independent variables taken under study. The degree of correlation among the factors is different with the highest correlation value of taste $(r=0.544, p<0.05)$ followed by ambience $(r=0.518, p<0.05)$, location $(r=0.466, p<0.05)$, and price of the fast food $(r=0.337, p<0.05)$. The least correlated factor is price $(\mathrm{r}=0.337)$ and highest correlated factor is taste $(0.544)$ with consumer preference. The result demonstrates all the independent variables have positive and significant relationship with dependent variable at 1 percent level of significance because $\mathrm{p}$ value is less than 0.05 .

\section{Regression Analysis}

Linear regressions have been used to explore the impact of independent variables on dependent variable.

From the model summary table, the $\mathrm{R}$ value $=0.519, \mathrm{R}^{2}=0.675$ and adjusted $\mathrm{R}^{2}=0.66$. Adjusted $\mathrm{R}^{2}$ shows that 66 percent of the consumer preference can be explained by four independent variables (price, taste, ambience and location) and remaining $33 \%$ of consumer preference will explain by other factors for the buying of fast food.

From the ANOVA table, the estimated regression model is statistically significant $(\mathrm{F}=11.745, \mathrm{p}=$ $.000, \mathrm{df}=221$ ). Four independent variables (taste, price, ambience, and location) have been good predictors for brand preference.

Table 3 Multiple Regression Results of Dependent and Independent Variables

\begin{tabular}{|c|c|c|c|c|c|}
\hline \multirow{2}{*}{ Model } & \multicolumn{2}{|c|}{ Unstandardized Coefficients } & \multirow{2}{*}{$\begin{array}{c}\text { Standardized Coefficients } \\
\text { Beta }\end{array}$} & \multirow[t]{2}{*}{$\mathrm{T}$} & \multirow[t]{2}{*}{ Sig. } \\
\hline & B & Std. Error & & & \\
\hline (Constant) & 2.313 & 0.289 & & 8.01 & 0 \\
\hline Taste & 0.274 & 0.103 & 0.24 & 2.65 & 0.01 \\
\hline Price & 0.032 & 0.082 & 0.037 & 0.39 & 0.69 \\
\hline Ambience & 0.262 & 0.064 & 0.328 & 4.11 & .000 \\
\hline Location & 0.217 & 0.108 & 0.214 & 2 & 0.05 \\
\hline
\end{tabular}

Dependent Variable: Consumer Preference

Source: Market Survey 2018 
Above table shows coefficients value, the higher the beta coefficient is the most important factors that influence for consumer preference. The result shows that there is significant impact of taste on consumer preference because the beta coefficient value is 0.274 . It indicates that one unit change in taste will lead to 0.274 unit of change in consumer preference. Ambience also has significant impact on consumer preference. The beta coefficient value of ambience is 0.262 . It indicates that one unit change in ambience will lead to 0.262 unit of change in consumer preference. Similarly, location also has significant impact on consumer preference with the beta coefficient value of 0.217 . It indicates that one unit change in location will lead to 0.217 unit of change in consumer preference for fast food items selection. But there is no significant impact of price has consumer preference which has only 0.032 beta coefficient value. It also indicates that one unit change in price will lead to 0.032 unit of change in consumer preference.

The result of above table shows the factors influencing consumer preference of fast food items of the respondents taken under study is accordingly with taste, price, ambience, and location.

\section{Conclusion}

The main objective of this research is to investigate the underlying factors that determine the consumer preference of fast food items. The primary focus was to analyze the relationship and the impact of four dependent variables under the study with the consumer preference of fast food items in the Kathmandu valley which is the dependent variable under the study. The collected information 226 respondents by using structured questionnaire were analyzed though frequency distribution, descriptive analysis, correlation analysis and regression analysis using SPSS 20 software.

The analysis of the primary data displays that among taste, price, ambience and location. Taste has the dominant impact on consumer preference for the fast food they consume. In addition, consumers are more cautious about the taste of fast food while consuming the fast food.

According to the Pearson correlation results, there is high correlation between taste and consumer preference in the buying of the fast food. Secondly, ambience has high correlation with the consumer preference. Location is another factor high correlation with the consumer preference. The least correlated factor is price of the fast food. The respondents are least concerned about the price for consuming the fast food.

This study used multiple regression analysis to test the effects of four independent variables (taste, price, ambience and location) on the consumer preference for consuming the fast food items. Out of four independent variables, taste, ambience and location significantly influence on the consumer preference of fast food items. The leading factor is taste, followed by ambience and location of the fast food. However, in this study, price factor do not have significant influence on consumer's preference.

The conclusion drawn by the researchers is the study has major opinions of the consumers and the consumer preference is greatly influenced by the taste of the fast food items, attractive and comfortable ambience to consumer the fast food and accessible location to consume the fast food. The remaining factor i.e. price of the fast food tends to have less influence on consumer preference.

\section{Managerial Implications}

This study has evidenced that taste has been one of the important factors to influence the consumer preference of fast food items. Ambience is another factor that has influence the consumer preference of fast food items. Accessible location is the last factor that has a positive relationship with consumer preferences.

In this context of Nepal, there has not been much research conducted in this area. Hence, more indepth study should be conducted related to this topic. Fast food market in Nepal is constantly evolving which means new consumer are emerging. Therefore, future research can be conducted with a larger sample that can bring more accuracy in data analysis.

This study provides some significant knowledge and information to the fast food restaurant business people and distributors to focus more on taste of the fast food, ambience and accessible location of the fast 
Vol. 4, No. 1

food in Nepal. The study unveils that fast food producer and manufacturer should be carefully re-think its strategy when producing and distributing fast food items and focuses more on taste of the fast food, proper ambience and accessible location to consume the fast food.

\section{References}

Akhter, M. (2017). Consumer Attitude toward Fast Food Consumption: A Study on University Students in Dhaka City. Asian Journal of Humanity, Art and Literature, 4.

Akkucuk, U., \& Nooshabadi, J. E. (2016). The Impact of Brands on Consumer Buying Behavior: An Empirical Study On Smartphone Buyers. Journal of Research in Business \& Social Science, 5 (4), 1-16.

Ashraf, M., Akhtar, S., \& Noor, S. (2014). Consumer behavior in fast food marketing in Bangladesh: a case study. Developing Country Studies, 4 (9), 34-46.

Blackwell, R. D., Miniard, P. W., \& Engel, J. F. (2005). Consumer Behavior. Thomson South-Western,Boston: South-Western College Pub.

Comer, J. C., \& Wikle, T. A. (2008). Worldwide Diffusion of the Cellular Telephone. The Professional Geographer, 60 (2), 252-269.

Das, D. (2012). An empirical study of factors influencing buying behaviour of youth consumers towards mobile handsets: A case study in coastal distrcts of Odisha. Asian Journal of Research in Business Economics and Management, 2 (4), 68-82.

Dean, A. M., Mei, W. O., \& White, C. J. (1999). Analysing service quality in the hospitality industry. Managing Service Quality:An International Journal, 9 (2), 136-143.

Deivanai, D. (2016). Factors influencing to Preference of Fast Food Restaurants. IOSR Journal of Business and Management, 18 (6), 20-25.

Dorsch, M. J., Grove, S. J., \& Darden, W. R. (2000). Consumer Intentions to use a service

Guleria, D. (2015). A study of consumer preference for smartphone: A case os Solan town of Himachal Pradesh. International Journal of Management Research \& Review, 5 (3), 193-200.

Hussey, R., \& Collis, J. (2003). Business Research: A Practical Guide for Undergraduate and Postgraduate Students. Houndmills, Basingstoke, Hampshire: Palgrave Macmillan.

Joseph, B., \& Khannal, V. (2011). A comparative study of buying behavior of mobile phones among rural,semirural and urban teenagers of Nepal. Asian Journal of Management Research, 2 (1), 35-48.

Joshi, S., Jog, Y., Chirputkar, A., Shrivastava, N., \& Doshi, R. (2016). Factors Affecting Smartphone Purchase among Indian Youth: A Descriptive Analysis. Indian Journal of Science \& Technology, 9 (15), $1-10$.

Karthikeyan, P. (2011). A study on brand preference of mobile phone customers with reference to erode city. International Journal of Research in Commerce, 1 (7), 66-77.

Kaynak, E., Aksoy, S., \& Kucukemiroglu, O. (1996). Consumer Preferences for Fast Food Outlets in a Developing Country. Journal of Euromarketing, 5 (4).

Kharel, U. (2015, October). Why fast food?

Kotler, P. (2004). Ten Deadly Marketing Sins: Signs and Solutions. Hoboken(NJ): John Wiley \& Sons.

Kotler, P., \& Armstrong, G. (2008). Principles of Marketing (12 ed.). Boston: Prentice Hall.

Kotler, P., \& Armstrong, G. (2012). Principles of Marketing (14 ed.). England: Pearson Education Limited.

Kumar, D., \& Radhika, S. (2013). A study on customers preference towards fast foods with references to Coimbatore city. 2 (11).

Liu, Y., \& Jang, S. (2009). Perceptions of Chinese restaurants in the U.S.: What affects customer satisfaction and behavioral intentions. International Journal of Hospitality Management, 28, 338-348.

Malasi, J. M. (2012). Influence of Product Attributes on Mobile Phone preference among university students: A Case of Undergraduate students. International Journal of Academic Research in Economics 
and Management Sciences, 1 (6), 10-16.

Malviya, S., Saluja, M. S., \& Thakur, A. S. (2013). A Study on the Factors Influencing Consumer's Purchase Decision towards Smartphones in Indore. International Journal of Advance Research in Computer Science and Management Studies, 1 (6), 14-21.

Mohan, A. (2014). Consumer behaviour towards smartphone industry in Indian market. Dublin Business School.

Monteiro, P. A. (2000). FACTORS THAT INFLUENCE THE DECISION OF PATRONS TO DINE AT.

Nagle, T. T., \& Holden, R. K. (2002). Strategy and Tactics of Pricing: A Guide to Profitable Decision Making.

Nagle, T. T., \& Holden, R. K. (2002). The Strategy and Tactics of Pricing: A Guide to Profitable Decision Making ( 3 ed.). Boston: Prentice Hall.

Nazir, I., Nasir, A., Ahmed, M. A., Zafar, H., \& Zahid, Z. (2014). Impact of Different Determinants on Customer's Satisfaction Level (A case of Fast Food Restaurant). International Journal of Business and Management Invention, 3 (9), 32-40.

Nguyen, N., \& Leblanc, G. (2002). Contact personnel, physical environment and the perceived corporate image of intangible services by new clients. International Journal of Service Industry Management, 13 (3), 242-262.

Pakola, J., Marjukka, P., Svento, R., \& Karjaluoto, H. (2003). An Investigation of Consumer Behavior in Mobile Phone Markets in Finland. Submission to 32nd EMAC Conference, Track:New Technologies and E-Marketing, (pp. 1-7). Scotland.

Phan, T. A., \& Nguyen, T. H. (2016). An Analysis of Factors Impact on Customer Satisfaction in Vietnam Restaurants: Case of Fast Food Restaurants. International Journal of Business and Management Review, 4(6), 1-17.

Platania, M., \& Privitera, D. (2006). "Typical products and consumer preferences: the "soppressata" case". British Food Journal, 108 (5), 385 - 395.

Powers, M., Scheule, B., Israeli, A., \& Gordon, K. L. (2016). College students' health attitudes, perceptions of restaurant menu items, and purchase intentions. Journal of Foodservice Business Research, 20 (4).

Rahim, A., Safin, S. Z., Kheng, L. K., Abas, N., \& Ali, S. M. (2016). Factors Influencing Purchasing Intention of Smartphone among University Students. Procedia Economics and Finance, 37, 245-253.

Rapurohit, R. S., \& Vasita, D. M. (2011). Consumer Preferences and satisfaction towards various mobile phone service providers. Gurukul Business review, 7, 1-11.

Saif, N., Razzaq, N., Amad, M., \& Gul, S. (2012). Factors Affecting Consumers' Choice of Mobile Phone Selection in Pakistan. European Journal of Business and Management, 4 (12), 16-26.

Sata, M. (2013). Consumer Buying Behavior of Mobile Phone Devices. Journal of Marketing and Consumer Research - An Open Access International Journal, 2, 8-14.

Sethi, A., \& Chandel, A. (2015). Consumer Buying Preference Towards Entry Level Smartphone. International Journal of Applied Business and Economic Research, 13 (3), 1173-1189.

Singh, K. G. (2012). Customer Preferences and Satisfaction towards Mobile Phone-The Case of Selected District of Punjab. Asian Journal of Research Marketing, 1 (4), 16-31.

Sternthal, B., \& Craig, S. C. (1982). Consumer Behavior: An Information Processing Perspective. Prentice Hall.

Subramanyam, D., \& Venkateswarlu, M. (2012). Factors Influencing Buyer Behaviour of Mobile Phone Buyers in Kadapa District. Indian Journal of Research, 1 (11), 3-5.

Suki, N. M. (2013). Students' demand for smartphones: Structural relationships of product features, brand name, product price and social influence. Campus-Wide Information Systems, 30 (4), 236-248.

Vidya, P. \& Vasanthi, S. (2014). Factors Influencing Consumers in the Selection of Fast Food Retail Outlets-a Study With Special Reference to Consumers in Coimbatore City. INDIAN JOURNAL OF APPLIED RESEARCH, 4 (7). 
Vol. 4, No. 1

Anand, M.P., Maiya, M., Mukherjee, S., Munjal, Y.P., Wander, G.S., Kamat,(2014). Consumer Preference and Spending Pattern in Indian. nternational Journal of Scientific and Research Publications, 4 (2).

Stamoulis, Kostas G., Pingali, Prabhu and Shetty, Prakash; Emerging Challenges for Food and Nutrition Policy in Developing Countries, Vol. 1, No. 2, 2004, pp. 154-167

Islam, N. \& Ullaha, S. (2010). Factors affecting consumers' preferences on fast food items in Bangladesh Journal of Applied Business Research 26(4):131-146 · July 2010 with8,338 Reads 